\title{
Postfire Effects in Siberian Larch Stands on Multispectral Satellite Data
}

\author{
E. G. Shvetsov ${ }^{a, b}$, * and E. I. Ponomarev ${ }^{a, b}$ \\ ${ }^{a}$ Sukachev Institute of Forest, Siberian Branch, Russian Academy of Sciences, Krasnoyarsk, 660036 Russia \\ ${ }^{b}$ Siberian Federal University, Krasnoyarsk, 660041 Russia \\ *e-mail: eugeneshvetsov11@yandex.ru
}

Received August 1, 2019; revised September 23, 2019; accepted September 23, 2019

\begin{abstract}
This work considers the dynamics of vegetation indices and surface temperature of postfire areas of different ages in larch forests of the permafrost zone of Siberia obtained using long-term Terra/MODIS satellite imagery. Landsat/ETM and OLI satellite images were preliminarily classified to analyze the degree of pyrogenic disturbance in the sample of postfire sites. An increase in the average temperature of the underlying surface of the postpyrogenic areas by $3.9-4.6^{\circ} \mathrm{C}$ was recorded, depending on the degree of disturbance of the litter, which is $15-30 \%$ of the average background values. Compared with background values, the deviation (decrease) in the next postfire year was $22 \%$ for the NDVI and $72 \%$ for the NBR index. Recovery of the NDVI to background values required 7-10 years after the fire. The recovery period for the surface temperature and the NBR index are significantly higher, that is, 15 years and more. Moreover, for $15-20$ years after the fire, the temperature anomalies of the underlying surface remain significant.
\end{abstract}

Keywords: remote sensing data, vegetation index, surface temperature, Siberia, Terra/MODIS

DOI: $10.1134 / \mathrm{S} 1995425520010096$

\section{INTRODUCTION}

Fire frequency is steadily on the rise in the forests of boreal zone, including Siberian larch stands, as reported by multiple studies in recent years (Kharuk and Ponomarev, 2017; Shvidenko and Shchepashchenko, 2013; Flannigan et al., 2009; Bartalev et al., 2015). Wildfire is the most significant factor in the forest disturbance in the permafrost zone of Siberia under current conditions. Observations with the involvement of satellite tools allow for an evaluation of the true scale of fire processes in Siberia, which lays the proper foundation for the further study of the state of the forest ecosystems in the boreal zone and forecasting their stability under the conditions of climate change.

Changes in the surface energy balance and an increase in downward flux through the soil profile are recorded as early as at the time of fire exposure (Jiang et al., 2012). However, the long-term effects induced by the subsequent alteration of surface reflectance, prolonged anomalies of heat transport (Jin et al., 2012), an increase in average annual temperatures of upper soil horizons, and thawing depth of seasonally-thawed layer reported for similar conditions of Siberia (Ponomarev and Ponomareva, 2018; Skryabin and Varlamov, 2013) and Alaska (Brown et al., 2015) are the most significant. Soil temperature has been shown to vary considerably due to the disturbance of thermal insulating properties of the litter and ground cover (Anisimov and Beloluts- kaya, 2004), resulting in the degradation of the permafrost near-surface layers (Desyatkin et al., 2012; Anisimov and Sherstyukov, 2016). In this context, the variability of fire conditions and parameters, as well as magnitudes and trends of pyrogenic disturbance of the larch stands in Siberia bring into focus the objective to predict changes in the underlying surface reflectance and heat budget on postfire sites in large areas, which can be accomplished instrumentally using the satellite data. Additionally, the degree of pyrogenic disturbance determined by fire type and intensity can be classified based on multispectral imaging data (French et al., 2008). For these objectives, appropriate results can be produced by indices using the shortwave IR spectrum range, e.g., NBR (French et al., 2008), the effectiveness of which was assessed in a number of works (Bartalev et al., 2010; Chu et al., 2016).

The primary goal of this work is to perform a quantitative assessment of recovery dynamics on postfire sites of larch stands based on the remote sensing of the anomaly range of vegetation indices and temperature of the underlying surface. The following aspects were considered: (1) the long-term variability of time series of vegetation indices (NDVI and NBR) and surface temperature and (2) the correlation of their values with a degree of pyrogenic disturbance classified based on information from satellite imagery of moderate resolution. 


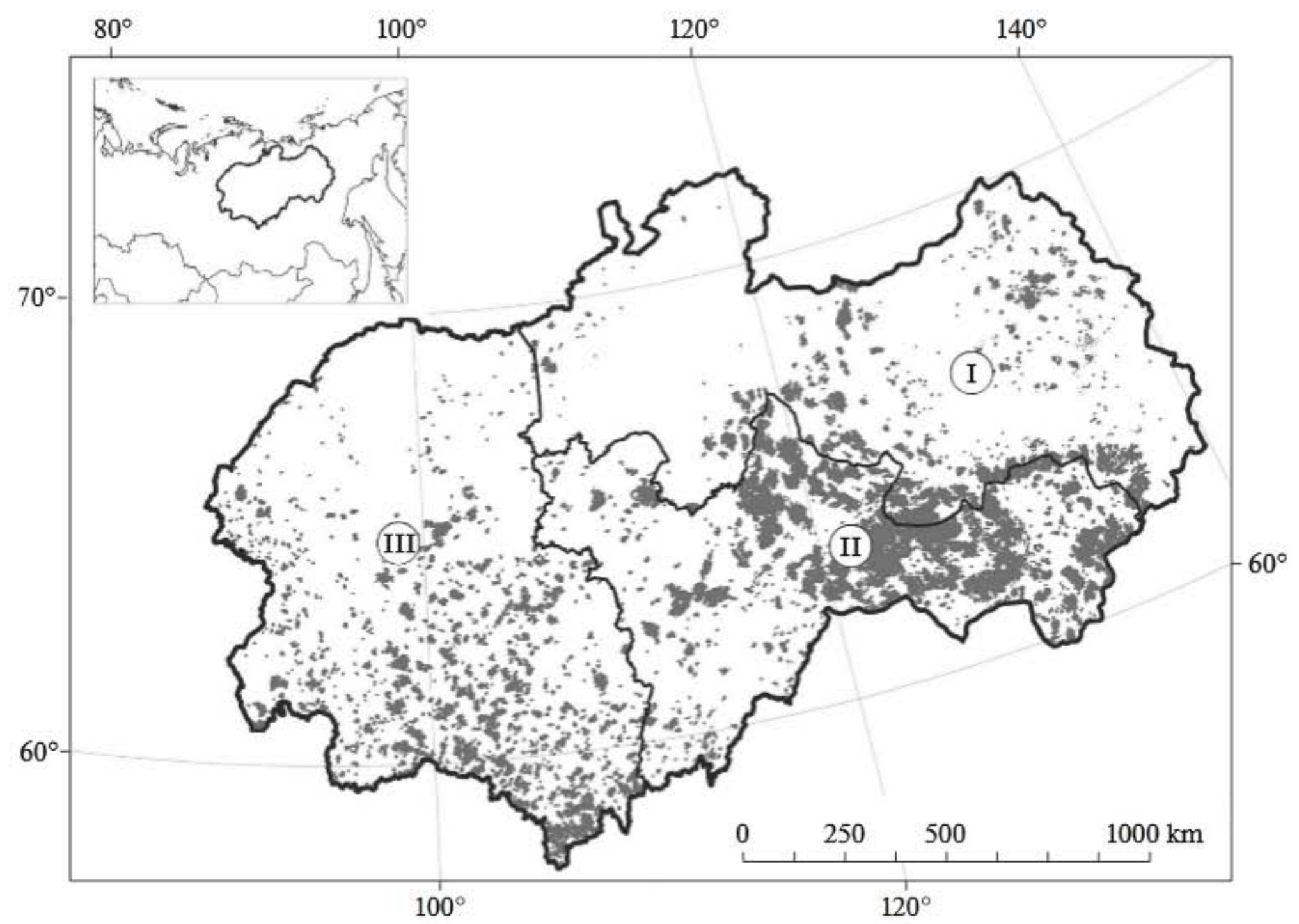

Fig. 1. Study area. Fires larger than 1500 ha are shown in gray according to (Ponomarev and Shvetsov, 2015) remote sensing data over 2000-2018. Forest vegetation districts (Prikaz..., 2014): (I) East Siberian boreal permafrost district, (II) East Siberian forest-tundra transition and open boreal woodlands district, and (III) Central Siberian Plateau boreal district.

\section{MATERIALS AND METHODS}

\section{Study Area}

The research was conducted for three forest vegetation zones (districts), namely, Central Siberian Plateau boreal district, East Siberian boreal permafrost district, and East Siberian forest-tundra transition and open boreal woodlands district (Prikaz..., 2014) within boundaries of $60^{\circ}-70^{\circ} \mathrm{N}, 90^{\circ}-140^{\circ} \mathrm{E}$ (Fig. 1). The total area is 2.4 million $\mathrm{km}^{2}$. According to vector maps of National Snow and Ice Data Center (Brown et al., 2002), the area is located in a permafrost zone and includes more than $80 \%$ of continuous permafrost extent.

The dominant species in the tree stand composition is larch (Larix sibirica and Larix gmelinii) covering $80-90 \%$ of the forest area (Rastitel'nost' SSSR, 1990). Pine forests account for approximately $5 \%$; deciduous and dark coniferous species each have 3\% (Rastitel'nost' SSSR, 1990). The soil cover is formed under conditions of sharply continental relatively dry and cold climate and the extent of permafrost. Taiga cryogenic and gleyey cryogenic soils are prevalent, as are pale yellow cryogenic soils (Urusevskaya et al., 2011).

\section{Baseline Data and Methods}

This study employs the long-term archives of MODIS (Moderate Resolution Imaging Spectroradiometer) imagery. MOD09A1 Version 6 product (Vermote, 2015) with spatial resolution of $500 \mathrm{~m}$ and a wavelength range of $0.46-2.15 \mu \mathrm{m}$ (bands $1-7$ ) corrected for atmospheric conditions was used as a source of data on surface reflectance and for the subsequent calculation of the vegetation indices. In addition to measurements made in spectral bands, the product comprises quality indicators for the data.

Surface temperature was estimated using MOD11A2 Version 6 product (Wan et al., 2015). The product comprises measurements of underlying surface temperature averaged over 8 days, as well as information with respect to quality of the obtained data. The original spatial resolution is $1000 \mathrm{~m}$; however, the source data were rescaled to $500 \mathrm{~m}$ spatial resolution to be used in conjunction with MOD09A1.

Forest burned-area mapping was done using MCD64A1 v. 6 (Giglio et al., 2016). The product uses as inputs Terra and Aqua satellite data, has spatial resolution of $500 \mathrm{~m}$, and encompasses pixel-level mask of burned areas. Fire dates, coordinate reference, and 
size of fire polygons were monitored through fire database of Sukachev Institute of Forest, Siberian Branch, Russian Academy of Sciences (Ponomarev and Shvetsov, 2015).

All the MODIS products are defined in sinusoidal projection.

The additional data involved vector vegetation layer for Siberia obtained based on Vegetation of the Soviet Union map (1990). The layer was subjected to reprojection and rasterization procedures to convert it to a format appropriate for processing in conjunction with MODIS subject-specific products. As a result, each pixel in MODIS products was assigned a polygon of vector vegetation map (scale $1: 1000000$ ) with reference to the dominant tree stand.

For vegetation state quality indicator, the study employs the Normalized Difference Vegetation Index (NDVI), as well as the Normalized Burn Ratio (NBR). The NDVI value was calculated from surface reflectance measurements in ranges of $0.62-0.67 \mu \mathrm{m}$ and $0.841-0.876 \mu \mathrm{m}$ (MODIS bands 1 and 2, respectively):

$$
N D V I=\frac{R 2-R 1}{R 2+R 1},
$$

NBR was calculated as normalized difference between bands 2 and $7(2.105-2.155 \mu \mathrm{m})$ :

$$
N B R=\frac{R 2-R 7}{R 2+R 7},
$$

where $\mathrm{R} 1, \mathrm{R} 2$, and $\mathrm{R} 7$ are reflectance values in MODIS bands 1,2 , and 7, respectively.

Normalized burn ratio and differenced normalized burn ratio (dNBR) (Key and Benson, 2006) are commonly employed to evaluate the degree of pyrogenic disturbance in various forest ecosystems from satellite data (Escuin et al., 2008; French et al., 2008). Differenced ratio dNBR, calculated as $\left(\mathrm{NBR}_{\text {prefire }}-\mathrm{NBR}_{\text {postfire }}\right)$, where $\mathrm{NBR}_{\text {prefire }}$ is an NBR value before a fire and $\mathrm{NBR}_{\text {postfire }}$ after the fire, respectively, was used in the present work to classify a degree of pyrogenic disturbance in the region. The dNBR index value equal to the 75th percentile was taken as threshold. Pixels with dNBR below this value were classified as lightly or moderately disturbed. Sites with dNBR value above the threshold were characterized by a high degree of disturbance. The dNBR index calculation as the prefire NBR index value involved the value obtained for the season preceding a fire and as the postfire index value in the summer season after the fire.

This work considers the sample of postfire sites with the recorded occurrences of wildfires in 2001, 2002, and 2006. During these seasons, a great number (60-140) of large fires (at least $1500 \mathrm{ha}$ ) were recorded in each of the considered forest vegetation districts. Time series of vegetation indices and surface temperature over the period from mid-June to the end of August (161th-233rd days of the year) were created for each season of 2000 throughout 2018. Using the
MODIS standard product QA flags, "bad" retrievals associated with cloudiness or smoke were excluded from consideration. Seasonal average was determined for the times series. Thus, 19 final values of NDVI and NBR indices, as well as the underlying surface temperature, were received for each pixel within the boundaries of the considered districts. Burn masks combining all fire-affected sites were created for each of the three fire seasons of 2001, 2002, and 2006. The burn masks served to define the sites further analyzed for postpyrogenic dynamics.

The obtained data were compared against characteristics of undisturbed (background) sites in the similar physical-geographical, forest vegetation, and meteorological conditions. To estimate the background values, the composite images of the study area were divided into fragments of $100 \times 100$ pixels $(\sim 50 \times$ $50 \mathrm{~km}$ ). For each of the fragments, sample was selected from pixels, which were not classified as pyrogenically disturbed, according to the MCD64A1 product. Such samples were averaged; standard deviations were calculated for both vegetation indices and the temperature.

Deviations from background values were analyzed at the pixel level. The index deviation from the background value was estimated using $\mathrm{Z}$-scores from the ratio:

$$
Z=\frac{\sqrt{\left(V-V_{b}\right)^{2}}}{\sigma_{b}},
$$

where $V$ and $V_{b}$ represent postfire and background values of the considered parameters (vegetation index or temperature) and $\sigma_{b}$ is a standard deviation of the background value.

Thus, the $Z$-score characterizes the number of standard deviations, by which the value of the parameter on a fire-disturbed site differs from the background.

\section{RESULTS}

According to the results of satellite remote sensing, the total burn area exceeded 26 million ha in the study region over the period of 2000-2018. The total cumulative larch stand disturbance in the study area accounts for more than $10 \%$ of the regional total forest area. The interannual burned area varies considerably, ranging from 4000 to 3 million ha, and constitutes 2.5 million ha on average. The largest burned areas were reported from East Siberian boreal permafrost district (Republic of Yakutia), which is more than 12 million ha, or $45 \%$ of the total area burned in the region. There is an overall upward trend in the burned area for the considered territory (Fig. 2).

On postfire sites, the maximum deviation of the vegetation indices and underlying surface temperatures from the background values were observed the year following fire exposure. The most significant 


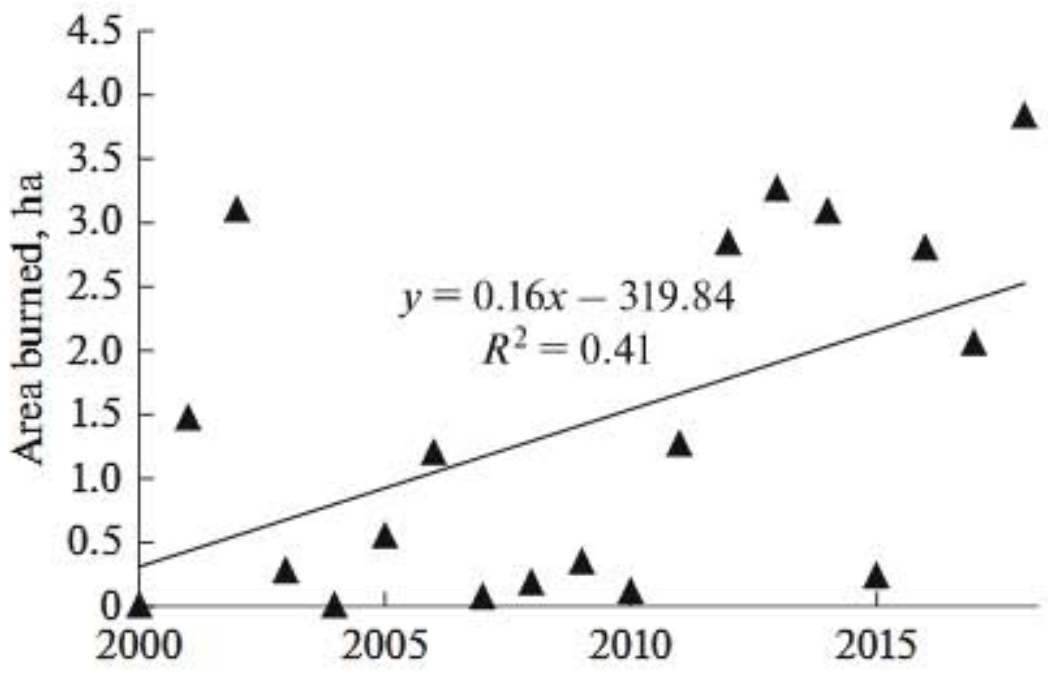

Fig. 2. Burned area dynamics in the study region over 2000-2018 based on remote sensing data. Areas larger than 1500 ha were considered.

amplitudes were recorded when using the normalized burn ratio (NBR) as an interpretive spectral sign (Table 1).

Sites of high and moderate degrees of disturbance exhibited well-marked differences in the recovery trend dynamics (according to dNBR). The value of the initial anomaly recorded during the first year of postfire observations differed nearly twice between these disturbance classes. Thus, for the NBR index, the mean value of relative deviation $Z$ constituted 7 (for sites of a high degree of vegetation and soil cover disturbance) and 4 (for the moderately disturbed), respectively (Fig. 3). The NDVI index and temperature had less pronounced differences in the amount of deviation during the first year after the fire; that is, heavily disturbed sites featured 1.5-2 times higher anomaly values when compared with sites of a moderate degree of disturbance.

In the case of moderately disturbed sites, the values of the considered parameters more closely approached the background values (deviation of less than $1 \sigma_{\mathrm{b}}$ ) when compared with heavily disturbed ones after $10-$ 15 years of recovery. The minimum time lag required to reach a deviation level of $1 \sigma_{b}$ relative to the background values was observed for NDVI index variance $(\sim 5$ years after the fire). At the same time, the underlying surfacetemperature anomalies were recorded over at least 1520 years after pyrogenic exposure (Fig. 3 ).
Based on the analysis of images with a moderate spatial resolution (Landsat 7), regions with the highest degree of pyrogenic disturbance (assessed using the NBR index) are also characterized by the largest anomalies of the underlying surface temperature. Thus, Fig. 4 illustrates the spatial distribution of the NBR index and surface underlying temperature based on Landsat 7 for the 2002 fire. The image was taken 12 weeks (for different parts of burned areas) after active combustion had ceased. Abnormal NBR values (below 10 percentile) are seen to coincide well with abnormal underlying surface temperature values (more than 90 percentile). Furthermore, sites of heavy pyrogenic disturbance (low NBR values) exhibited temperature anomalies even 16 years after the fire (August 2018) when compared with the background and partially recovered burn sites (Fig. 4c).

\section{DISCUSSION}

\section{Pyrogenic Disturbance of the Study Area}

As previously reported based on satellite data (Kharuk and Ponomarev, 2017; Bartalev et al., 2015), in 2001 and 2002 seasons, the majority of fires were recorded in the larch stands of the continuous permafrost extent zone. In 2006 a considerable part of fires occurred in the areas with discontinuous and patchy extents of permafrost. Forests with dominant pine tree stands accounted for approximately $30 \%$ of all burned areas in 2006.

No significant differences were observed in a degree of pyrogenic disturbance among the three forest vegetation districts in the study area. Figure 5 presents a histogram of distribution of the number of "fire" pixels (image pixels detected as an active combustion zone) dependent on the degree of pyrogenic disturbance expressed in terms of the dNBR index. Thus, the dNBR index values were relatively equal for Central Siberian Plateau boreal district and East Siberian boreal permafrost district (Table 2). The smaller mean value for sample from the East Siberian foresttundra transition and open boreal woodlands district is determined by a high share of fire pixels with low dNBR values ( 0.1 and less). The latter constitute approximately $25 \%$ of the total number. This can probably be attributed to the fact that, in the areas occupied by open woodlands, the dNBR index

Table 1. Values of anomalies during the first year and 10 years after fire

\begin{tabular}{l|c|c|c|c|c|c|c|c|c}
\hline \multirow{2}{*}{ Parameter } & \multicolumn{4}{|c|}{ First year after fire } & \multicolumn{4}{c|}{ Ten years after fire } & Recovery lag \\
\cline { 2 - 10 } & mean value & $\sigma$ & $\sigma_{b}$ & $\begin{array}{c}Z \\
(\min -\max )\end{array}$ & mean value & $\sigma$ & $\sigma_{b}$ & $\begin{array}{c}Z \\
(\min -\max )\end{array}$ & $\begin{array}{l}\text { time, years } \\
\text { NBR }\end{array}$ \\
NDVI & 0.32 & 0.08 & 0.03 & $3-8$ & 0.11 & 0.08 & 0.03 & $1.7-2.8$ & $>20$ \\
Temperature, ${ }^{\circ} \mathrm{C}$ & 0.13 & 0.06 & 0.04 & $2-3$ & 0.03 & 0.07 & 0.04 & $0.9-1.1$ & $7-10$ \\
\hline
\end{tabular}



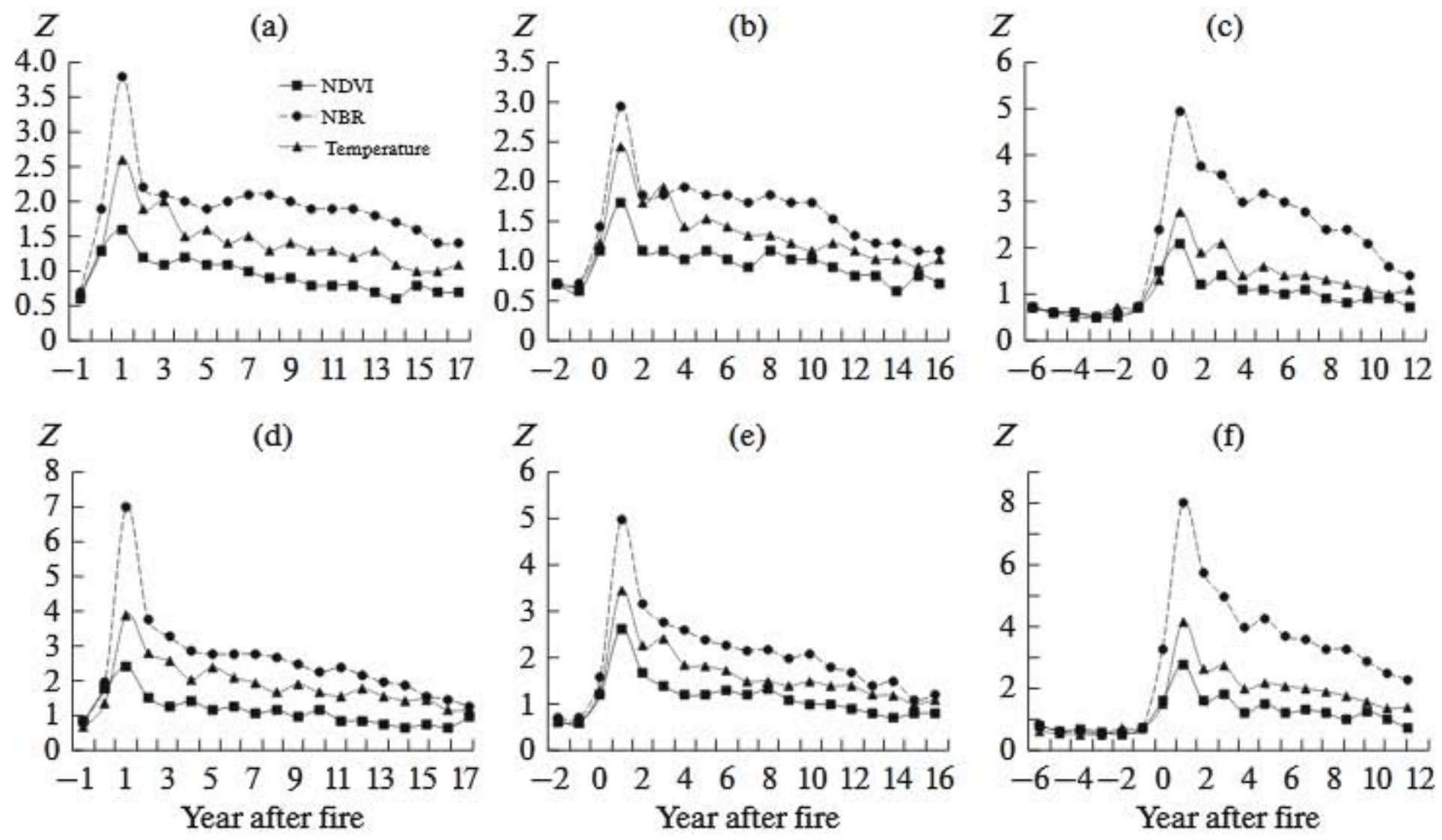

Fig. 3. Averaged time series of relative deviations of vegetation indices and temperatures in relation to background values for three forest vegetation district: (a, d) East Siberian forest-tundra transition and open boreal woodlands district, (b,e) East Siberian boreal permafrost district, and (c, f) Central Siberian Plateau boreal district. Time series $(a-c)$ correspond to sites of moderate degree of pyrogenic disturbance and $(\mathrm{d}-\mathrm{f})$ correspond to sites of high pyrogenic disturbance.

changes little, even providing a heavy pyrogenic exposure (Miller and Thode, 2007).

The major proportion of dNBR variance $\left(R^{2} \sim 0.69-\right.$ 0.75 ) was explained by the variance of postfire NBR values for the sample from a postfire site regardless of the forest vegetation district. At the same time, the prefire NBR value explained the proportion of the dNBR index variance at a level of $R^{2} \sim 0.05-0.09$. The results agree with the earlier findings reported, e.g., for postfire areas in North America boreal forests (Jin et al., 2012). The recorded dNBR values prove to be the most sensitive to the postfire state of the forest canopy and litter.

\section{Postpyrogenic Dynamics of Vegetation Indices and Underlying Surface Temperature}

The fact that vegetation indices, relying on measurements in near- and shortwave infrared wavebands, are characterized by more considerable pyrogenic changes when compared with NDVI was also reported by other authors (Gerard et al., 2003; Cuevas-Gonzalez et al., 2009).

The analysis of variance revealed that statistically significant differences among mean values of NBR, NDVI, and underlying surface temperature persist for samples of the background and "fire" pixels at a significance level $95 \%(p<0.001)$ over $12-18$ years after the fire (based on data from Terra/MODIS imagery conducted in 2018). Importantly, no significant differences in the considered parameters were recorded between the considered sites before fire.

Vegetation indices, using the shortwave IR band (NBR), are sensitive to the canopy structure and moisture content. They demonstrate larger amplitudes of postfire changes and require a longer period to recover to prefire values when compared with NDVI (Gerard et al., 2003). Thus, in the case of the 2001 fires, the NBR index approached a deviation of

Table 2. Mean values of the dNBR index on postfire sites for each forest district (standard deviation for a significance level at $p<0.05)$

\begin{tabular}{l|c|c|c|c}
\hline \multicolumn{1}{c|}{ Forest district } & $\begin{array}{c}\text { Number of considered } \\
\text { post fire sites }\end{array}$ & $\begin{array}{c}\text { Number of considered } \\
\text { "fire" pixels }\end{array}$ & dNBR & $\sigma$ \\
\hline East Siberian boreal permafrost district & 63 & 178236 & 0.33 & 0.18 \\
Central Siberian Plateau boreal district & 147 & 78976 & 0.32 & 0.16 \\
East Siberian forest-tundra transition & 102 & 67644 & 0.24 & 0.18 \\
and open boreal woodlands district & & & \\
\hline
\end{tabular}


(a)

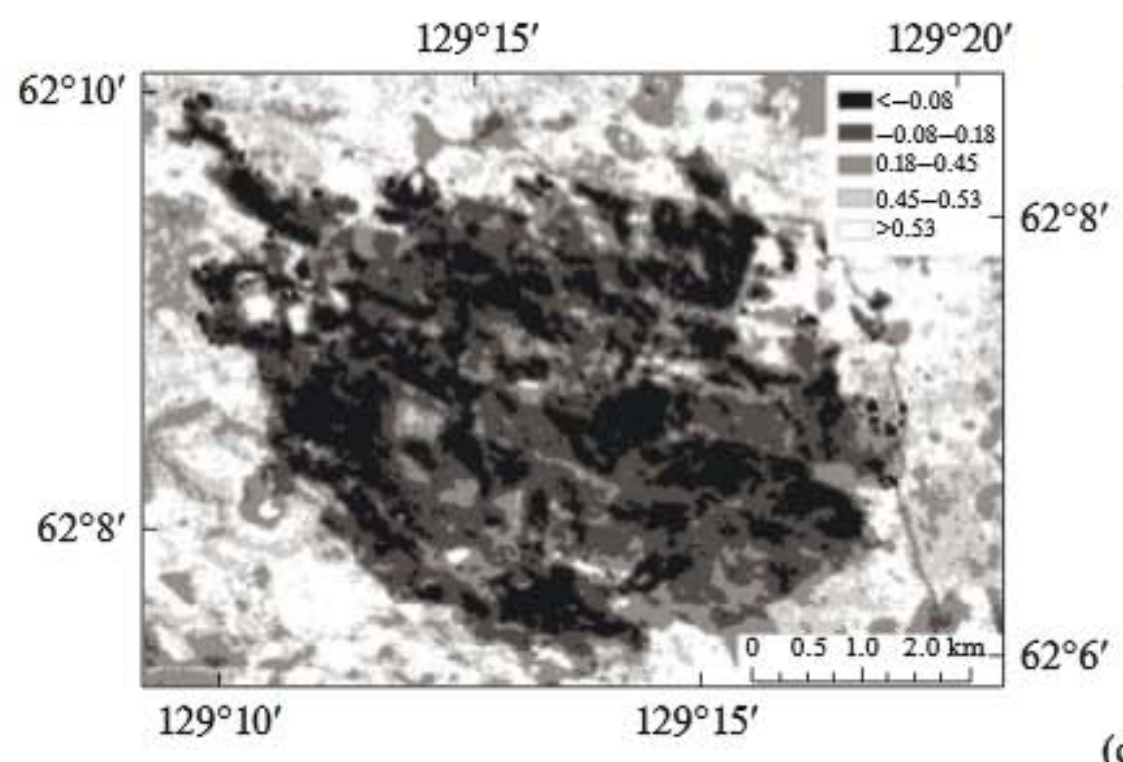

(b)

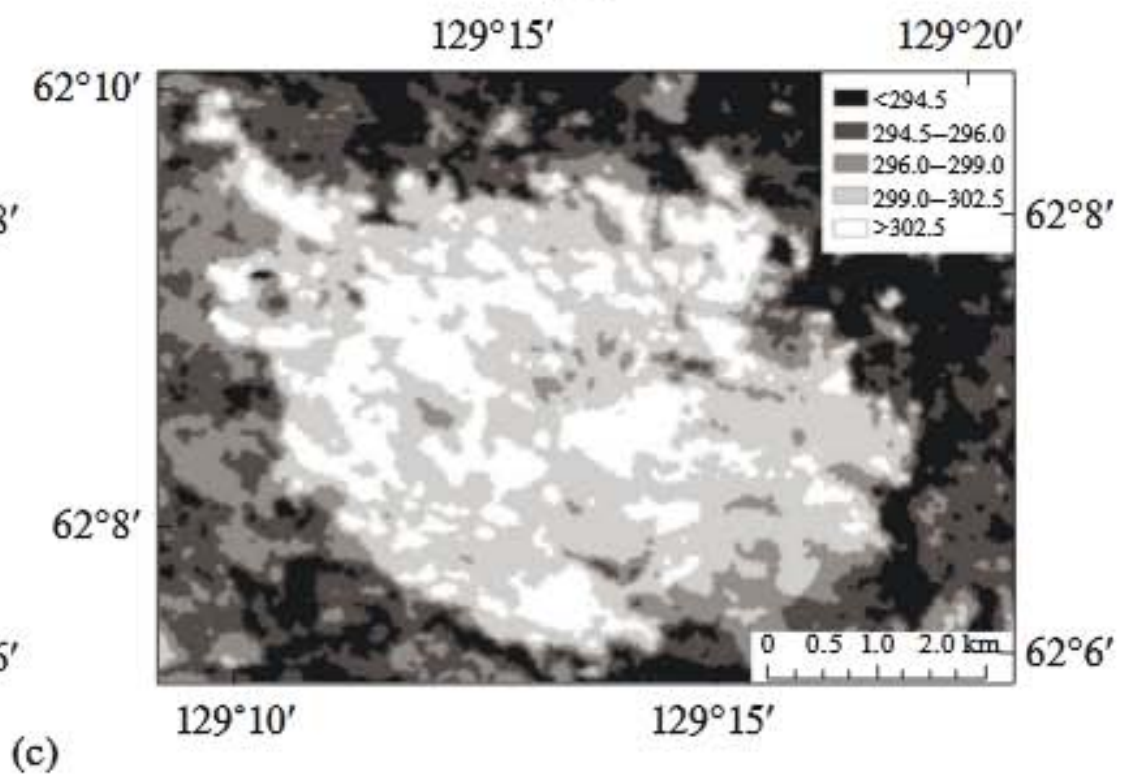

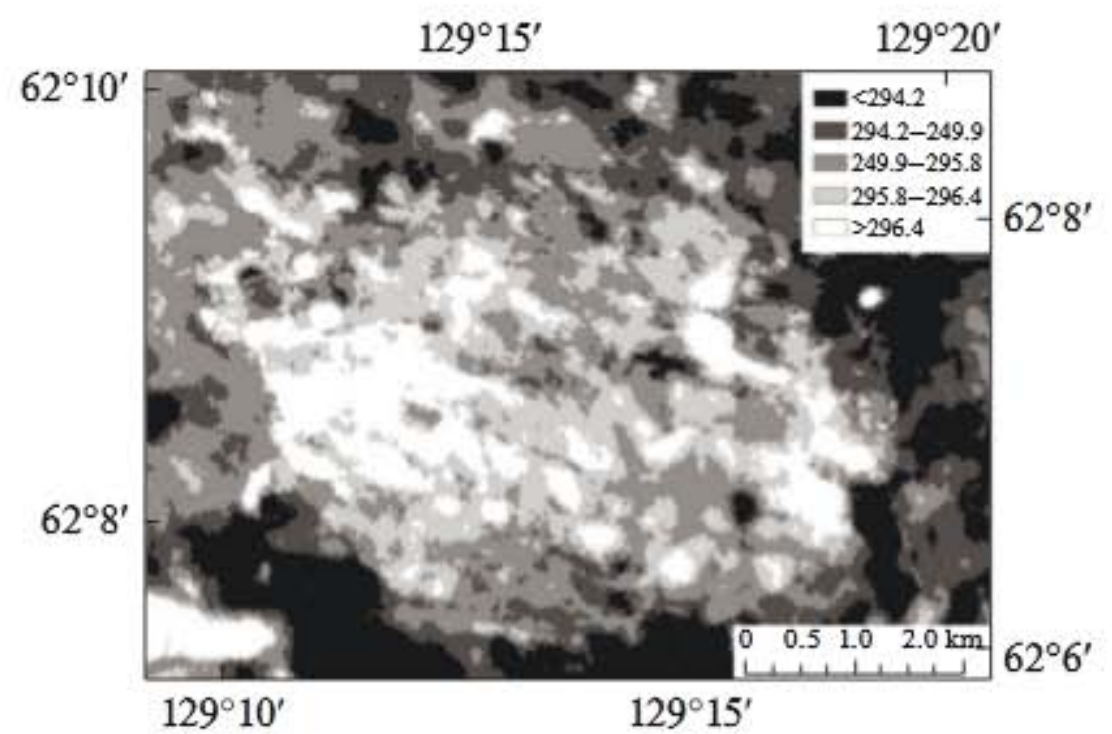

Fig. 4. Spatial distribution of (a) NBR index and underlying surface temperature (K) for burned area in (b) 2002 and (c) 2018 based on Landsat 7 data.

$1.4-1.5 \sigma_{\mathrm{b}}$ from the background value only $12-15$ years later (Fig. 6). The 2018 imagery data show minimum deviations for the 2002 fires at $1.1 \sigma_{b}$; i.e., the mean NBR value for burned pixels was approximately $8 \%$ below the background value. For comparison, the NDVI index had approached the background values (deviations constituted less than $1 \sigma_{\mathrm{b}}$ ) by 2008, 2012, and 2014 for fires that occurred in 2001, 2002, and 2006 , respectively. This is as little as $2 \%$ difference with (below) the background value and lies within the limits of relative measurement error. Thus, the NDVI index requires $7-10$ years to recover to the background values (deviation less than $1 \sigma_{\mathrm{b}}$ ).

Estimates of the amount of time needed for vegetation indices to recover to background values after pyrogenic exposure vary significantly depending on the region. Thus, the 9-year recovery period is reported for boreal forests in North America (Hicke et al., 2003). At the same time, a period of recovery longer than 13 years is reported for Central Siberia (Cuevas-Gonzalez et al., 2009). These estimates appear to be in line with our findings.
As for the underlying surface temperature, the time necessary to revert to the background values is at least 15-20 years; i.e., it exceeds the recovery period for

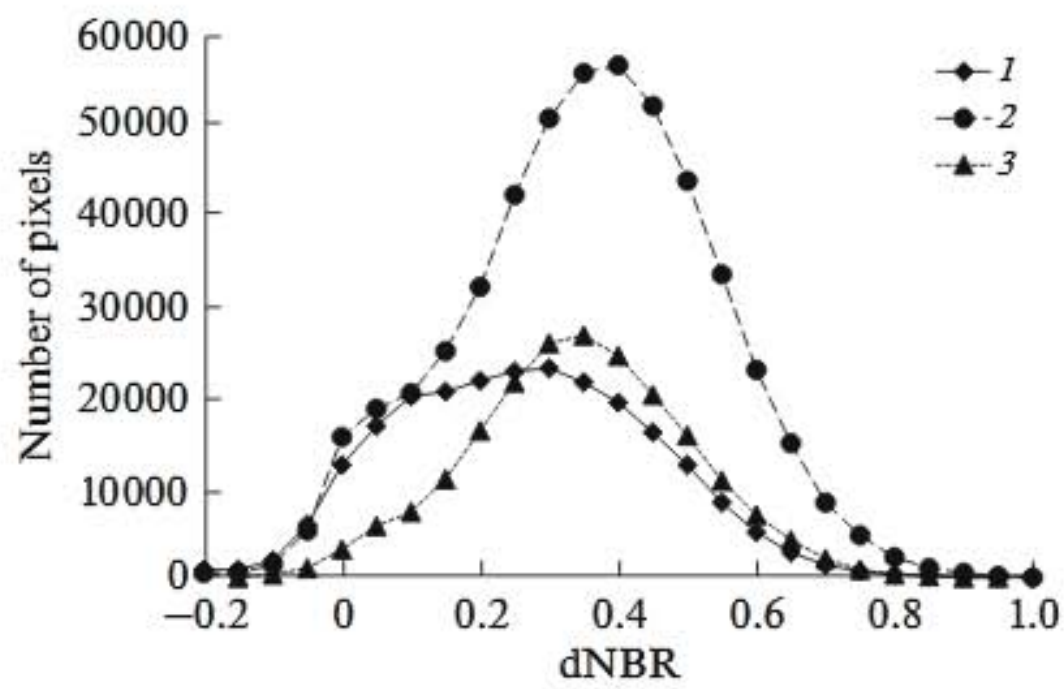

Fig. 5. Histograms of dNBR index for pixels of images corresponding to postfire sites, 2000-2018: (1) East Siberian forest-tundra transition and open boreal woodlands district, (2) East Siberian boreal permafrost district, and (3) Central Siberian Plateau boreal district. 


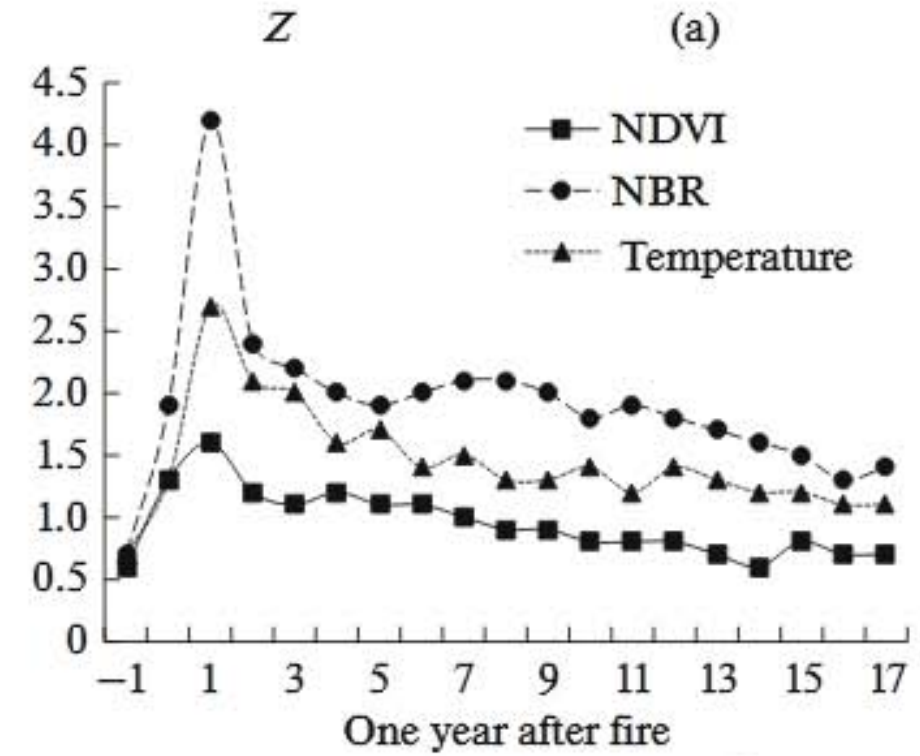

$Z$

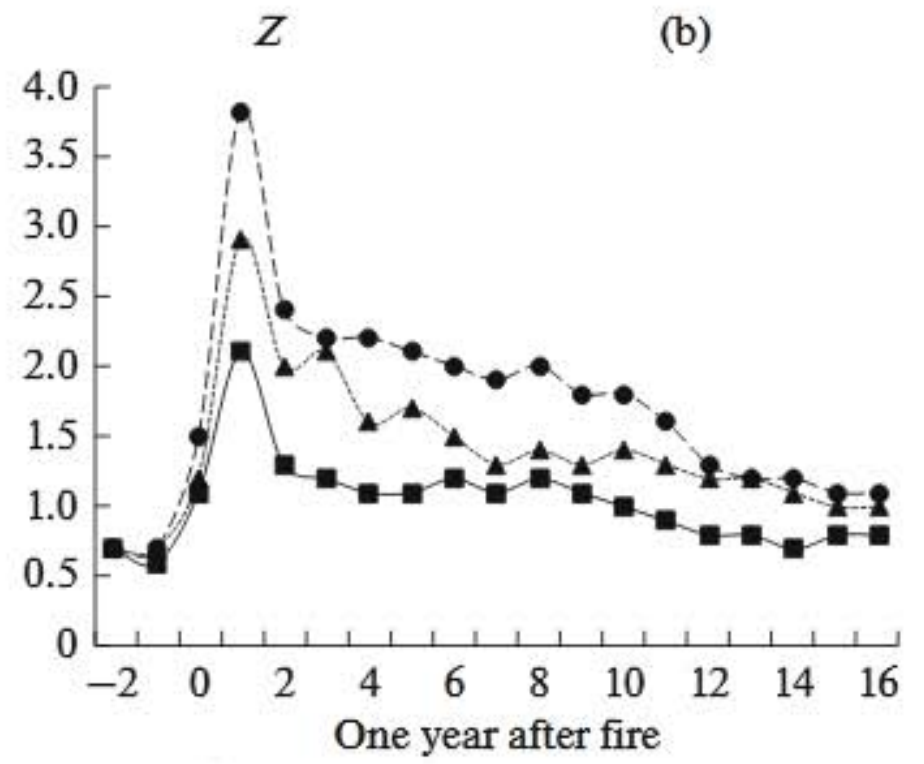

(c)

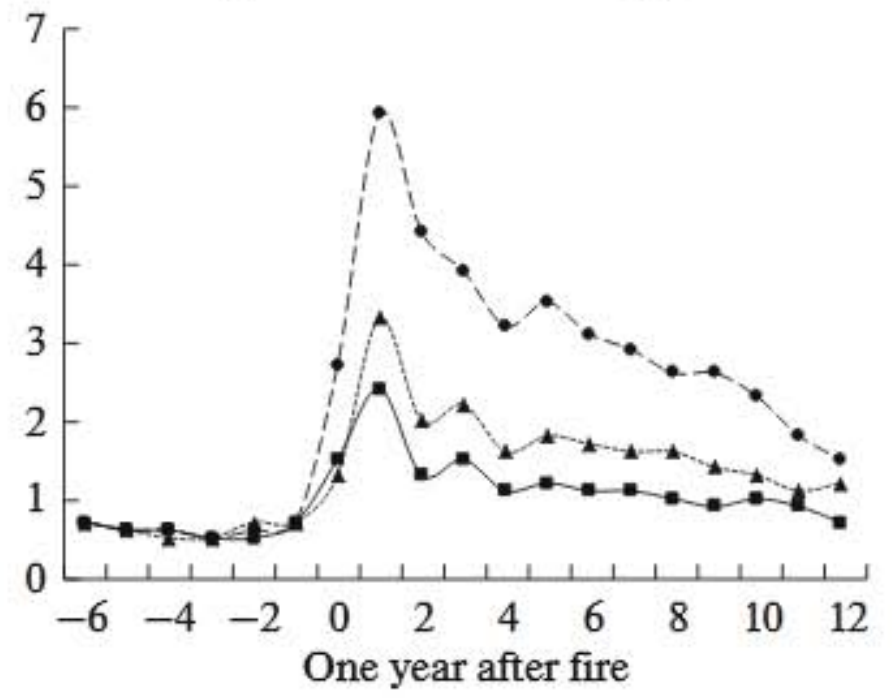

Fig. 6. Averaged time series of relative deviations of vegetation indices and temperatures from background values for three forest vegetation districts: (a) East Siberian forest-tundra transition and open boreal woodlands district, (b) East Siberian boreal permafrost district, and (c) Central Siberian Plateau boreal district.

NDVI more than twice (Table 1), which is confirmed by similar studies in the considered region (Ponomarev and Ponomareva, 2018). Thus, in the case of 2002 fires, the temperature deviation from the background had approached $1 \sigma_{\mathrm{b}}$ only by 2017 . No deviation (from background) value of $1 \sigma_{b}$ had been attained for the 2001 and 2006 fires by 2018 . In absolute terms, after 15 years of recovery succession, value of temperature anomalies exceeded mean values by $1.2 \pm 0.4^{\circ} \mathrm{C}$, which constituted 7-10\%.

\section{Variances of the Indices Dependent on the Degree of Pyrogenic Disturbance}

In the sites classified under a high degree of disturbance, the considered parameters required a considerably longer time period to recover to the background values. Thus, in the case of the normalized burn ratio (NBR), the deviations were greater than $\left(2 \sigma_{b}\right)$ even 10-12 years later after the fire. According to the 2018 imagery data, NDVI of burned areas differed from the background by the order of magnitude of $1 \sigma_{b}$; i.e., the recovery time was approximately 12 years. At the same time, mean temperature values remained different from the background by 1.1-1.4 $\sigma_{\mathrm{b}}$ (or approximately $1.3-1.6^{\circ} \mathrm{C}$ ). The sites burned by the high-intensity fires have temperature anomalies persisting for more than 15 years (Fig. 3), which makes the study area to stand out considerably. Thus, postpyrogenic temperature anomalies manifest themselves rather weakly already 2-3 years after the fire under Mediterranean conditions (Lopez Garcia and Caselles, 1991; Veraverbeke et al., 2012). For the heavily disturbed sites, the amount of postfire temperature changes (next year after the fire) constituted $4.6 \pm 1.1^{\circ} \mathrm{C}$ (excess of approximately $30 \%$ over the background value). For comparison, all sites displayed a mean temperature anomaly value of $3.9 \pm 1.2^{\circ} \mathrm{C}$.

Changes in the forest-litter parameters occurring as a result of pyrogenic exposure increase its thermal insulating properties, while a decrease in the albedo of burned areas combined with increased (due to fire impact) solar irradiance affects the temperature regime of the topsoil layer (Tarasov et al., 2008). Thus, according to our assessments, the surface mean temperature was observed to rise by $6.4^{\circ} \mathrm{C}$ during the next few weeks after the pyrogenic exposure. This agrees with the comparable estimates of $5-8^{\circ} \mathrm{C}$ reported by 
other studies (Lopez Garcia and Caselles, 1991; Ponomarev and Ponomareva, 2018; Amiro et al., 1999; Veraverbeke et al., 2012). Moreover, the maximum temperatures on particular postfire sites peaked at $41^{\circ} \mathrm{C}$, which is approximately $20^{\circ} \mathrm{C}$ excess over the background values.

Based on the findings of an analysis of the dynamics of the characteristics of the sites, it can be stated that the partial recovery of vegetation covers on postfire sites fails to offset changes translated into anomalies of surface temperature profile. According to field experiments, the complete recovery of the litter stock approaches the background values only by the 24-year term after the fire (Bezkorovainaya et al., 2017). Under these conditions, an excessive heat flux can have an impact on the state of near-surface soil layers while providing for temperature changes across various horizons, including permafrost. Clearly, this determines the dynamics of the reforestation process and should be considered when assessing the state and damage or observing the recovery processes in forests of permafrost zones using satellite techniques.

\section{CONCLUSIONS}

Time series analysis demonstrated the normalized burn ratio to be the most sensitive to pyrogenic exposure, which appears to be associated with its sensitivity to the moisture content of vegetation covers. The index is characterized by the highest level of postfire change and the greatest lag time needed to recover to the background values (within a range of one standard deviation). Thus, in the considered region, such a period amounts approximately 20 years and increases depending on the degree of initial postfire disturbance of the site. At the same time, the NDVI index sensitive to photosynthetic activity of plants requires approximately $7-10$ years to recover. The recovery period is about 5 years in the case of a moderate degree of pyrogenic disturbance.

The underlying surface temperature anomalies induced by pyrogenic exposure likewise persist for over 15 years after the fire. An amount of temperature anomaly (compared with the background) constitutes about $3.9 \pm 1.2^{\circ} \mathrm{C}$ during the first year after the fire and more than $4.6 \pm 1.1^{\circ} \mathrm{C}$ for sites classified under a heavy disturbance level. Excess of temperature over the background values on postfire sites is $15-25 \%$, sporadically peaking at a level of $30 \%$.

\section{FUNDING}

This work was financially supported by the Russian Foundation for Basic Research, project no. 0356-2019-0009; the government of Krasnoyarsk krai; and the Krasnoyarsk Krai Foundation for Scientific and Engineering Science Work project no. 18-41-242003 "Modeling and Remote Sensing of Effects Induced by Thermal Anomalies of Underlying Surface in the Seasonally Thawed Layer of Soils of Cryolithozone in Siberia" and project no. 18-05-00432 "Impact of Climate Change on Forests of Siberia: Analysis of Forest Area Fire Frequency, Increment for Accretion in Conifers, and Tree-Stand Vital State and Productivity."

\section{COMPLIANCE WITH ETHICAL STANDARDS}

Conflict of interests. The authors declare that they have no conflict of interest.

Statement on the welfare of animals. This article does not contain any studies involving animals performed by any of the authors.

\section{REFERENCES}

Amiro, B.D., MacPherson, J.I., and Desjardins, R.L., BOREAS flight measurements of forest-fire effects on carbon dioxide and energy fluxes, Agric. For. Meteorol., 1999, vol. 96, pp. 199-208.

https://doi.org/10.1016/S0168-1923(99)00050-7

Anisimov, O.A. and Sherstyukov, A.B., Role of natural climate factors in transformation of permafrost zone of Russia, Kriosfera Zemli, 2016, vol. 20, no. 2, pp. 90-99.

Anisimov, O.A. and Belolutskaya, M.A., Impact of anthropogenic warming on permafrost conditions in models: vegetation effect, Russ. Meteorol. Hydrol., 2004, no. 11, pp. 52-58.

Bartalev, S.A., Egorov, V.A., Krylov, A.M., Stytsenko, F.V., and Khovratovich, T.S., Study of the possibilities of firedisturbed forest state estimation using multispectral satellite measurements, Sovrem. Probl. Distantsionnogo Zondirovaniya Zemli Kosm., 2010, vol. 7, no. 3, pp. 215-225.

Bartalev, S.A., Stytsenko, F.V., Egorov, V.A., and Lupyan, E.A., Satellite assessment of fire-caused forest mortality in Russia, Lesovedenie, 2015, no. 2, pp. 83-94.

Bezkorovainaya, I.N., Borisova, I.V., Klimchenko, A.V., Shabalina, O.M., Zakharchenko, L.P., Il'in, A.A., and Beskrovnyi, A.K., Effect of pyrogenic factor on biological activity of soils in conditions of permafrost area (Central Evenkia), Vestn. Krasnoyarsk. Gos. Agrar. Univ., 2017, no. 9, pp. 181-189.

Brown, J., Ferrians, O.J., Heginbottom, J.A., and Melnikov, E.S., Circum-Arctic Map of Permafrost and Ground Ice Conditions, Version 2, Boulder, CO: National Snow and Ice Data Center, 2002. https://nsidc.org/ data/ggd318.

Brown, D.R.N., Jorgenson, M.T., Douglas, T.A., Romanovsky, V.E., Kielland, K., Hiemstra, C., Euskirchen, E.S., and Ruess, R.W., Interactive effects of wildfire and climate on permafrost degradation in Alaskan lowland forests, J. Geophys. Res.: Biogeosci., 2015, vol. 120, pp. 1619-1637. https://doi.org/10.1002/2015JG003033

Chu, T., Guo, X., and Takeda, K., Temporal dependence of burn severity assessment in Siberian larch (Larix sibirica) forest of northern Mongolia using remotely sensed data, Int. J. Wildland Fire, 2016, vol. 25, pp. 685-698. https://doi.org/10.1071/WF15182

Cuevas-Gonzalez, M., Gerard, F., Balzter, H., and Rianos, D., Analyzing forest recovery after wildfire disturbance in boreal Siberia using remotely sensed vegetation indices, Global Change Biol., 2009, vol. 15, 
pp. $561-577$.

https://doi.org/10.1111/j.1365-2486.2008.01784.x

Desyatkin, R.V., Desyatkin, A.R., and Fedorov, P.P., Temperature regime of permafrost taiga soils of Central Yakutia, Kriosfera Zemli, 2012, vol. 16, no. 2, pp. 70-78.

Escuin, S., Navarro, R., and Fernández, P., Fire severity assessment by using NBR (Normalized Burn Ratio) and NDVI (normalized difference vegetation index) derived from LANDSATTM/ETM images, Int. J. Remote Sens., 2008, vol. 29, pp. 1053-1073. https://doi.org/10.1080/01431160701281072

Flannigan, M., Stocks, B., Turetsky, M., and Wotton, M., Impacts of climate change on fire activity and fire management in the circumboreal forest, Global Change Biol., 2009 , vol. 15 , no. 3 , pp. $549-560$. https://doi.org/10.1111/j.1365-2486.2008.01660.x

French, N.H.F., Kasischke, E.S., Halle, R.J., Murphy, K.A., Verbyla, D.L., Hoy, E.E., and Allen, J.L., Using Landsat data to assess fire and burn severity in the North American boreal forest region: an overview and summary of results, Int. J. Wildland Fire, 2008, vol. 17, pp. 443-462. https://doi.org/10.1071/WF08007

Gerard, F., Plummer, S., Wadsworth, R., Ferreruela, A., Iliffe, L., Balzter, H., and Wyatt, B., Forest fire scar detection in the boreal forest with multitemporal SPOTVEGETATION data, IEEE Trans. Geosci. Remote Sens., 2003 , vol. 41 , pp. $2575-2585$. https://doi.org/10.1109/TGRS.2003.819190

Giglio, L., Justice, C., Boschetti, L., and Roy, D., Collection 6 MODIS burned area product user's guide, 2016. https://doi.org/10.5067/MODIS/MCD64A1.006

Hicke, J.A., Asner, G.P., Kasischke, E.S., French, N.H.F., Randerson, J.T., Collatz, J., Stocks, B.J., Tucker, C.J., Los, S.O., and Field, C.B., Postfire response of North American boreal forest net primary productivity analyzed with satellite observations, Global Change Biol., 2003, vol. 9, pp. 1145-1157.

https://doi.org/10.1046/j.1365-2486.2003.00658.x

Jiang, Y., Zhuang, Q., and O'Donnell, J.A., Modeling thermal dynamics of active layer soils and near-surface permafrost using a fully coupled water and heat transport model, J. Geophys. Res.: Atmos., 2012, vol. 117. https://doi.org/10.1029/2012JD017512

Jin, Y., Randerson, J.T., Goulden, M.L., and Goetz, S.J., Post-fire changes in net shortwave radiation along a latitudinal gradient in boreal North America, Geophys. Res. Lett., 2012, vol. 39. https://doi.org/10.1029/2011JG001886

Key, C.H. and Benson, N.C., Landscape assessment: sampling and analysis methods, in FIREMON: Fire Effects Monitoring and Inventory System, General Technical Report no. RMRS-GTR-164-CD, Lutes, D.C., et al., Eds., Fort Collins, CO: US Forest Service, 2006, pp. LA1-LA51,

Kharuk, V.I. and Ponomarev, E.I., Spatiotemporal characteristics of wildfire frequency and relative area burned in larch-dominated forests of Central Siberia, Russ. J. Ecol., 2017, vol. 48, no. 6, pp. 507-512. https://doi.org/10.1134/S1067413617060042

Lopez-Garcia, M.J. and Caselles, V., Mapping burns and natural reforestation using Thematic Mapper data,
Geocarto Int., 1991, vol. 6, pp. 31-37.

https://doi.org/10.1080/10106049109354290

Miller, J.D. and Thode, A.E., Quantifying burn severity in a heterogeneous landscape with a relative version of the delta Normalized Burn Ratio (dNBR), Remote Sens. Environ., 2007, vol. 109, pp. 66-80. https://doi.org/10.1016/j.rse.2006.12.006

Ponomarev, E.I. and Ponomareva, T.V., The effect of postfire temperature anomalies on seasonal soil thawing in the permafrost zone of Central Siberia evaluated using remote data, Contemp. Probl. Ecol., 2018, vol. 11, no. 4, pp. $420-427$.

Ponomarev, E.I. and Shvetsov, E.G., Satellite survey of forest fires and GIS methods in result calibration, Issled. Zemli Kosm., 2015, no. 1, pp. 84-91.

Prikaz Minprirody Rossii no. 367 ot 18.08.2014 "Ob utverzhdenii Perechnya lesorastitel'nykh zon Rossiiskoi Federatsii $i$ Perechnya lesnykh raionov Rossiiskoi Federatsii" (red. ot 19.02.2019) (Order of the Ministry of Nature of Russia No. 367 of August 18, 2014 "On Approval of the List of Forest Belts in Russian Federation and the List of Forest Regions of Russian Federation" Revised on February 19, 2019), Moscow, 2014.

Rastitel'nost' SSSR: karta masshtaba 1: 4000000 (Vegetation of Soviet Union, Map Scale 1:4000000), Moscow: Glav. Uprav. Geod. Kartogr., 1990.

Shvidenko, A.Z. and Schepaschenko, D.G., Climate change and wildfires in Russia, Contemp. Probl. Ecol., 2013, vol. 6, no. 7, pp. 683-692.

Skryabin, P.N. and Varlamov, S.P., Thermal regime of grounds in disturbed landscapes of Central Yakutia, Kriosfera Zemli, 2013, vol. 17, no. 3, pp. 44-49.

Tarasov, P.A., Ivanov, V.A., and Ivanova, G.A., Specific temperature regime of soils in pine forests of middle taiga after near-surface fires, Khvoinye Boreal'noi Zony, 2008 , vol. 25 , nos. $3-4$, pp. 300-304.

Urusevskaya, I.S., Martynenko, I.A., and Alyabina, I.O., Soil map, Scale 1: 15000000 , Explanatory note, in Natsional'nyi atlas pochv Rossiiskoi Federatsii (National Atlas of Soils of Russian Federation), Alyabin, I.O., Dobrovol'skii, G.V., Urusevskaya, I.S., et al., Moscow: AST, Astrel', 2011, pp. 72-77.

Veraverbeke, S., Verstraeten, W.W., Lhermitte, S., Van De Kerchove, R., and Goossens, R., Assessment of post-fire changes in land surface temperature and surface albedo, and their relation with fire-burn severity using multitemporal MODIS imagery, Int. J. Wildland Fire, 2012, vol. 21, pp. 243-256. https://doi.org/10.1071/WF10075

Vermote, E.F., MOD09A1 MODIS Surface Reflectance 8-Day L3 Global 500m SIN Grid V006, NASA EOSDIS Land Processes DAAC, 2015. https://doi.org/10.5067/MODIS/MOD09A1.006

Wan, Z., Hook, S., and Hulley, G., MOD11A2 MODIS/Terra Land Surface Temperature/Emissivity 8-Day L3 Global $1 \mathrm{~km}$ SIN Grid V006 (Data set), NASA EOSDIS LP DAAC, 2015. https://doi.org/10.5067/MODIS/MOD11A2.006

Translated by E. Kuznetsova 